\title{
Survey to Evaluate Escape of Eucalyptus spp. Seedlings from Plantations in Southeastern USA
}

\author{
Mac A. Callaham Jr., ${ }^{1}$ John A. Stanturf, ${ }^{1}$ William J. Hammond, ${ }^{2}$ Donald L. Rockwood, ${ }^{3,4}$ \\ Evelyn S. Wenk, ${ }^{1}$ and Joseph J. O'Brien ${ }^{1}$ \\ ${ }^{1}$ Center for Forest Disturbance Science, USDA Forest Service, Southern Research Station, Athens, GA 30602, USA \\ ${ }^{2}$ Product Development, ArborGen Inc., Summerville, SC 29483, USA \\ ${ }^{3}$ Florida FGT LLC, Gainesville, FL 32635, USA \\ ${ }^{4}$ School of Forest Resources and Conservation, University of Florida, Gainesville, FL 32611, USA
}

Correspondence should be addressed to Mac A. Callaham Jr.; mac.callaham@gmail.com

Received 10 July 2012; Revised 8 December 2012; Accepted 17 December 2012

Academic Editor: Matias Kirst

Copyright ( 2013 Mac A. Callaham Jr et al. This is an open access article distributed under the Creative Commons Attribution License, which permits unrestricted use, distribution, and reproduction in any medium, provided the original work is properly cited.

\begin{abstract}
Interest in biomass-based energy in the southeastern Unites States has led to increased need for fast-growing tree species. Several Eucalyptus species exhibit characteristics that make them attractive in the bioenergy context. However, some of these also possess traits that suggest they could become invasive. To make a preliminary assessment of the risk of seedling establishment in the vicinity of Eucalyptus plantations, we conducted surveys at 3 sites in South Carolina and 16 sites in Florida. In South Carolina, no seedlings were detected in any sample transect. In Florida, we found seedlings within the boundaries of Eucalyptus plantations at 4 of the 16 sites surveyed. We also detected seedlings outside the boundaries of these same four plantations, but only two seedlings were detected at distances $>45 \mathrm{~m}$ from plantation boundaries. All seedlings from Florida were either E. amplifolia, E. robusta, or E. grandis. The most predictive variable evaluated was latitude, with $27^{\circ} \mathrm{N}$ being the highest latitude at which seedlings established with regularity. Results of this survey indicate that, under current conditions, the spread of Eucalyptus spp. from plantations should be possible to manage with appropriate monitoring, but this should be evaluated further before Eucalyptus spp. are adopted for widespread planting.
\end{abstract}

\section{Introduction}

Biomass-based energy as an alternative to fossil fuel-based energy has received increasing attention in recent decades, and one important source of bioenergy feedstock will be in the form of woody biomass [1]. Portions of the southeastern United States are well suited to provide substantial quantities of wood-based biomass because large areas of land are currently in forestry uses, and because of existing wood growing and processing infrastructure $[2,3]$. This production of woody biomass could be enhanced by departures from historical forestry practices and movement toward shorter rotations, and the adoption of short-rotation woody crop (SRWC) silvicultural practices. Part of successful SRWC management includes selection of appropriate tree species, with a suite of traits that make them particularly suitable for these practices including rapid growth rates, ability to coppice, and climatic tolerance $[4,5]$.

Several species of Eucalyptus are excellent candidates for use in SRWC, and these have been planted in experimental stands by forest industry in the southeastern USA since the 1950s. However, the effective range of planting for Eucalyptus species was demonstrated to be smaller than originally thought due to extremely harsh winter conditions in the early 1980s, and at that time, interest in large-scale planting of Eucalyptus faded (R.C. Kellison, personal communication). Since that time, advances such as genetic modification and identification of breeding stock with favorable cold tolerance characteristics have once again renewed industry interest in Eucalyptus as a potential source of bioenergy feedstock, or pulp and timber production [6]. 
Clearly, along with the potential benefits, both economic and environmental, of increased reliance on woody biomass for bioenergy feedstock [7], there are legitimate concerns surrounding the widespread adoption of this landuse, particularly when the tree species being considered are nonnative, and potentially invasive $[8,9]$. Eucalyptus species are known to be invasive in certain parts of the world and are particularly problematic in South Africa [10,11] and Chile [12], but in other countries such as Brazil, there is doubt as to whether Eucalyptus is likely to escape from planted stands [13]. In USA, Eucalyptus have been planted in California for more than 150 years, and these plantings involved more than 200 species in that time [14]. Of the $200+$ introduced to California, 18 species are considered "naturalized"- exhibiting spontaneous reproduction in their introduced range, but only two of these species are considered invasive species, and these of moderate or limited risk within the classification system of the California Invasive Plant Council [14]. Eucalyptus has also been planted in Florida for decades with extensive planting in the southern portion of the state beginning in the 1960s [15]. Again, Eucalyptus is known to spontaneously reproduce in Florida (as evidenced by the prevalence of advanced regeneration seedling orchards for production of planting stocks), but there has been little reporting of these plants spreading out of planted areas into surrounding lands (a search of peer-reviewed literature yielded no studies reporting field observations of Eucalyptus invasion in Florida).

Rejmánek and Richardson [16] suggest three reasons that Eucalyptus is less invasive than other widely cultivated trees and shrubs: Eucalyptus species have limited seed dispersal, high seedling mortality, and lack of compatible ectomycorrhizal fungi. The high seedling mortality is attributed to the lack of endosperm and dormancy mechanisms in Eucalyptus seed, requiring germinants to contact wet, bare soil quickly for seedlings to survive [16]. For example, in California, Eucalyptus seedlings are most likely to establish outside of planted groves where there are significant soil disturbances and where there is regular moisture from coastal fog drip [17].

However, in spite of these observations of limited spread of Eucalyptus into unmanaged habitats, some resistance to the idea of further planting of Eucalyptus in the southeastern USA remains. Using a tool (the Australian Weed Risk Assessment model [18], modified for local conditions [19]) that takes into account available information about plant lifehistory traits and other traits related to the establishment and spread of plants, Gordon et al. [20] evaluated several species that have been proposed for use in biofuel applications for the southeastern USA and predicted that several species of Eucalyptus had a high likelihood of becoming invasive. As a result, it was recommended that these species can be excluded from consideration as potential biofuel crop plants. Notably, these recommendations were made based solely on the predictions of the Australian Weed Risk Assessment model and did not incorporate field-based observations. Additionally, these authors state that the AWRA model could not separate those species that might naturalize without becoming invasive from those that will invade neighboring vegetation [20].
In any consideration of invasive species biology, it is important to utilize terminology that is consistent and representative of actual processes occurring in field settings [21]. Toward this end, we have adopted the framework presented by Blackburn et al. [22], as we consider this to be the most recent and comprehensive treatment of general stages, processes, and terminology to date. Thus, the process of plants exhibiting spontaneous reproduction in their introduced range is appropriately termed "naturalization." Naturalization of Eucalyptus in locations where the plant has already been intentionally planted is not necessarily seen as a negative outcome (i.e., the plant is intended to be there for some purpose). On the other hand, the term "invasion" should be applied to plants that are not only reproducing, but also spreading long distances (e.g., 100s of meters), and in large numbers (i.e., the plant now occupies lands where it is not intended to be).

Objectives for this study were to conduct field surveys in established plantations of Eucalyptus which varied in terms of Eucalyptus species planted, stand age, and surrounding landuses and determine the actual rate of seedling establishment as one potential measure of invasiveness for Eucalyptus in the southeastern USA.

\section{Materials and Methods}

We conducted field surveys to document seedling establishment in the vicinity of 19 planted stands of various species of Eucalyptus in South Carolina and Florida. The sites are characterized in terms of age and type of plantation, and the species used at each site in Table 1. The sampling design we used was specifically designed to be effective for the detection of rare events [23]. Briefly, the approach makes use of probability theory and knowledge about the properties of the Poisson distribution and negative binomial distribution to derive power formulae to give estimates of how many samples must be taken to achieve detection of events, in this case, seedling establishment. The equation used was

$$
n=-\frac{1}{m} *(\log \beta)
$$

where $n=$ the number of samples needed to detect the event of interest, $m=$ the mean frequency of occurrence of the event, and $\beta=$ the probability of sampling the event at least once given a particular value of $n$ (or "confidence level of the estimate," in the terminology of Green and Young [23]). In practice, $m$ frequently is not known until sampling is actually done, and therefore must be operationally defined a priori. Green and Young [23] suggest $m=0.1$ as one definition of "rare," but we adopted an even more rigorous definition for our survey of $m=0.05$. Because the actual number of plots that could be realistically sampled depended upon the size of the sampled stand, the value of $\beta$ (the calculated probability of actually sampling a seedling given the number of plots sampled, and an assumed frequency of 0.05 ) varied from site to site. The values of $\beta$ for our survey ranged from 0.877 to 0.999 and are reported for individual sites in Table 1 .

Our sampling strategy for detecting Eucalyptus seedlings was transect based. Each transect consisted of 30 cells of 


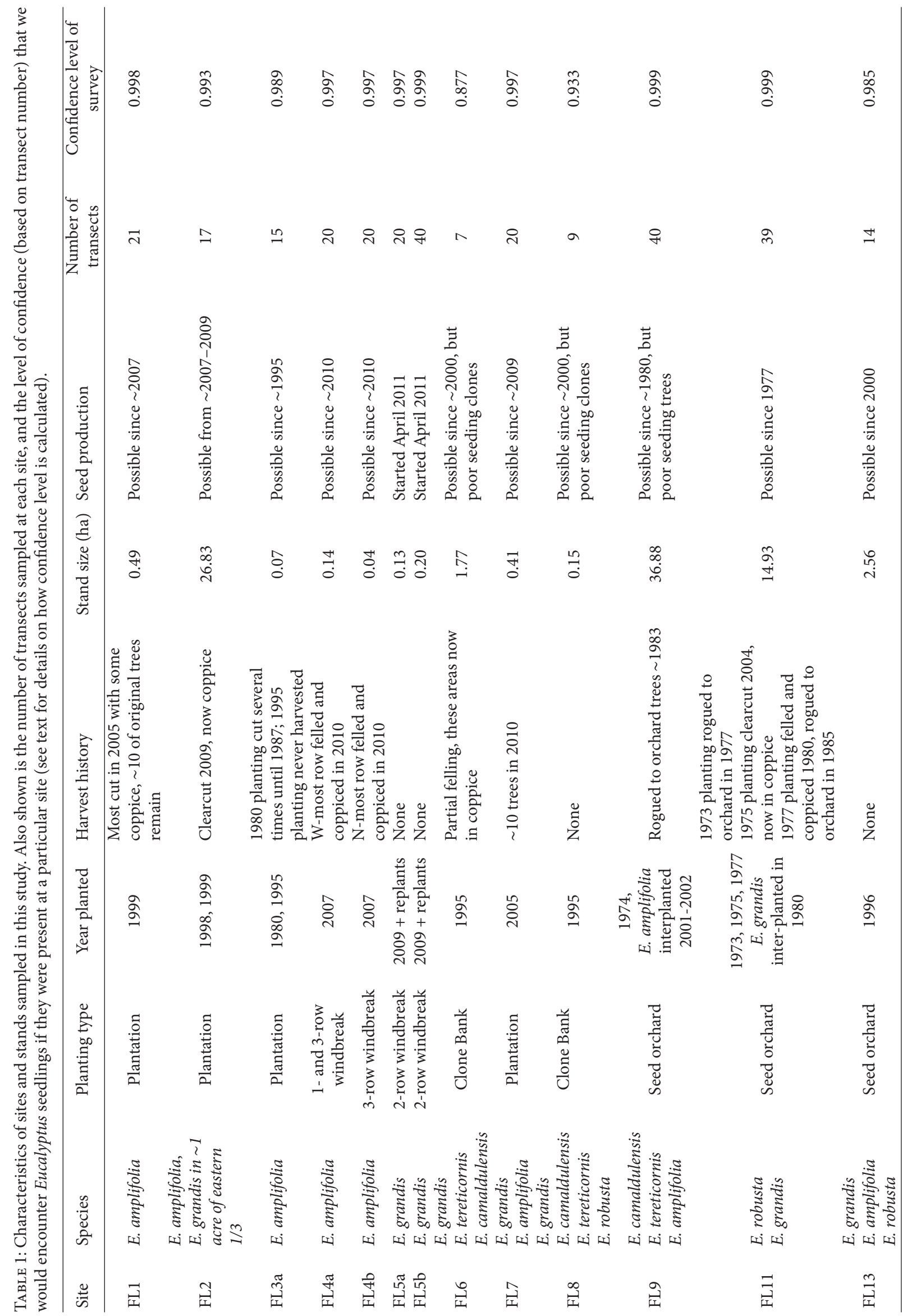




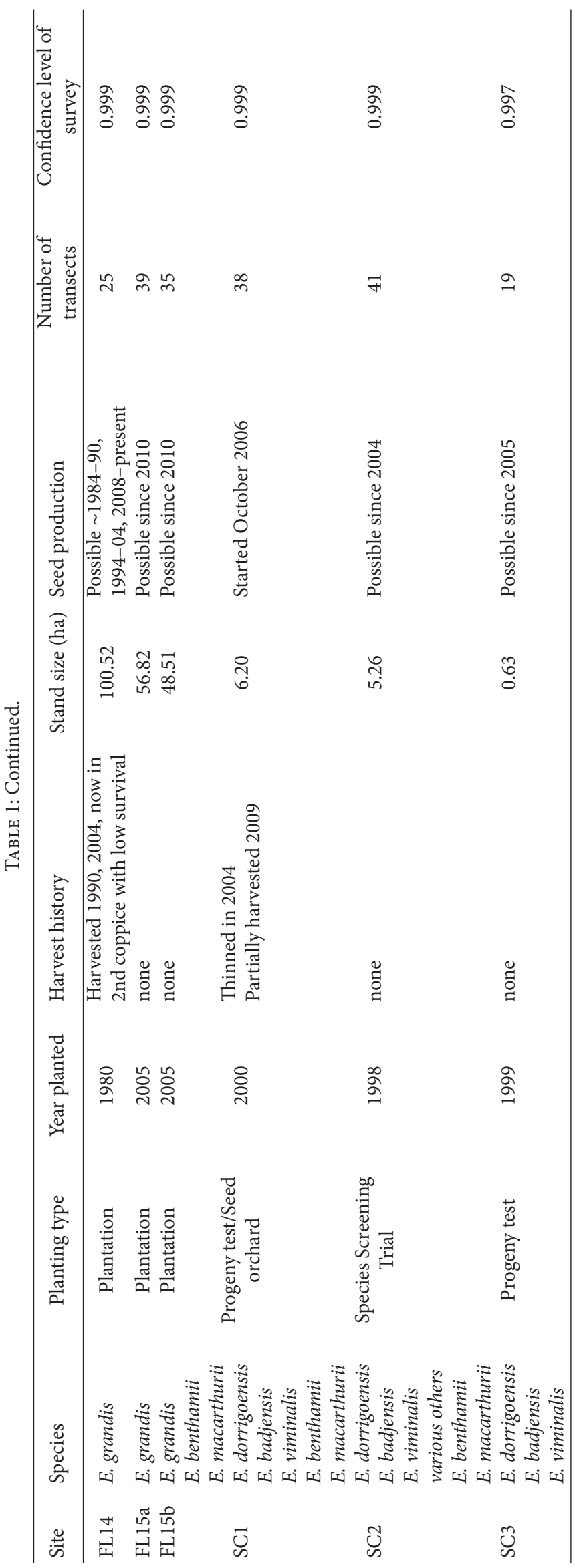


$3 \mathrm{~m} \times 3 \mathrm{~m}$ with a total length of $90 \mathrm{~m}$. Each transect was situated at the boundary of the Eucalyptus stand such that 5 cells $(15 \mathrm{~m})$ of the transect extended into the stand, and 25 cells $(75 \mathrm{~m})$ of transect extended away from the stand at an azimuth perpendicular to the stand boundary. We selected one of the 5 cells inside the stand boundary at random for initial sampling, and then we systematically sampled the cells falling on the transect at $15 \mathrm{~m}$ intervals from this initial cell throughout the length of the transect for a total of 6 cells sampled per transect (Figure 1). The number of transects at each site varied but in general the number and spacing was determined by taking the total length of the boundary of the Eucalyptus stand and dividing by 40 , with the resulting figure used as a standard distance to separate sampling transects. When the perimeter of the stand was less than $800 \mathrm{~m}$, the distance between transects was automatically set to $20 \mathrm{~m}$. At some stands either entire transects, or individual plots, had to be excluded because of property ownership concerns. In total, we sampled 479 transects containing $28393 \times 3 \mathrm{~m}$ plots from 16 sites in Florida and 3 sites in South Carolina. Due to the general rarity of seedling encounters and the general small size of plantations, in addition to the transect-based sampling we also conducted a general, non-quantitative, cruise of each stand, and noted the presence of any seedlings that were not encountered in the transect sampling.

Within each of the $3 \times 3 \mathrm{~m}$ sampling cells, we collected data on a suite of variables. These included the number of Eucalyptus seedlings, percent cover of ground-layer herbaceous vegetation, percent tree canopy cover, and percent cover of bare mineral soil. Percent cover estimates were recorded in the following classes: $1=0-5 \%, 2=6-25 \%, 3=$ $26-50 \%, 4=51-75 \%, 5=76-95 \%$, and $6=96-100 \%$.

Following field data collection, we used aerial photos of each site to characterize the general land use surrounding the sampled Euclayptus stands. We categorized the predominant land cover for every $3 \times 3 \mathrm{~m}$ plot on every sampling transect at all sites. The land cover types were classified as shown in Table 2. We then used the data for Eucalyptus seedling establishment to determine if there was a particular habitat type that was disproportionately associated with this phenomenon.

2.1. Data Analysis. We used simple correlations to examine the relationship between the total number of seedlings detected at each site (inside and outside the plantation boundaries), and characteristics such as plantation age, and plantation size. Some of our sites had trees of differing ages (different plantings), and for these sites, we used the age of the oldest trees at the site for our correlation analysis.

Because of a large number of zeros in our dataset, we elected to further analyze the presence of Eucalyptus seedlings with logistic regressions. We used logistic regression to model the dichotomous response variable presence/absence of Eucalyptus seedlings in a plot, as a linear combination of five predictor variables. The independent predictor variables included three continuous variables (latitude, canopy cover (\%), and bare ground (\%)), and two categorical variables (whether or not Eucalyptus had been previously planted at the location, and whether or not the location was a mesic

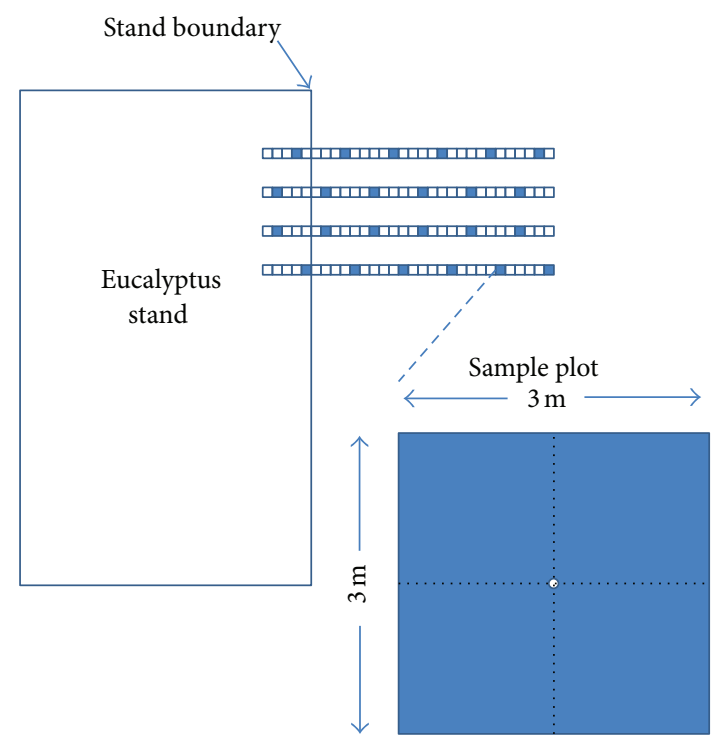

Figure 1: Schematic diagram of sampling design. Transects were $90 \mathrm{~m}$ in length, containing 30 cells $3 \times 3 \mathrm{~m}$. The first cell was randomly selected from the five cells inside the stand boundary, and then cells were systematically sampled every $15 \mathrm{~m}$ throughout the length of the transect. For example, in the 4 transects shown in the figure, only blue cells would be sampled for seedlings and environmental variables. Transects were oriented perpendicular to the boundary edge and evenly spaced around the entire Eucalyptus stand.

site or wetland). For all sites, the percent cover of ground layer vegetation and the percent bare ground were highly correlated with one another, and therefore, percent cover of ground layer vegetation was excluded from the analysis. Logistic regression was performed in SAS 9.2 using PROC LOGISTIC (SAS Institute Inc. 2008). Only 18 sites were included in the logistic regression because missing cover data prevented the inclusion of one site in South Carolina.

\section{Results}

Our sampling effort resulted in the detection of $85 \mathrm{Euca}$ lyptus seedlings total from all sites sampled. Of these, 54 seedlings were established within the boundaries of the planted stands with a generally decreasing number observed in plots further away from stand boundaries (Figure 2). We detected seedlings in our transects at 6 sites: FL1, FL9, FL11, FL14, FL15a, and FL15b. All seedlings were either Eucalyptus amplifolia, E. grandis, or E. robusta (Table 1). When we examined the relationship between the location (latitude and longitude) of each site relative to the number of seedlings detected outside the boundaries of the Eucalyptus plantations stands, there was a strong tendency for seedlings to be detected in the southern most-sites (Figure 3). Specifically, there was only a single seedling that was detected in our sampling plots above the $27^{\circ} \mathrm{N}$ latitude. We also noted an individual seedling in one of the South Carolina stands (not within our formal sampling plots), and this would have been well north of any other seedling detection. 
TABLE 2: A summary of the land cover types at each of the plots sampled from all sites surveyed, and the distribution of Eucalyptus seedlings among the land cover types.

\begin{tabular}{|c|c|c|c|c|}
\hline Land cover type & $\begin{array}{l}\text { Number of plots in land } \\
\text { cover type }\end{array}$ & $\begin{array}{l}\text { Number of Eucalyptus } \\
\text { seedlings in land cover } \\
\text { type }\end{array}$ & $\begin{array}{l}\text { Number of plots with } \\
\text { Eucalyptus seedlings }\end{array}$ & $\begin{array}{c}\text { Proportion of plots in } \\
\text { land cover type with } \\
\text { seedlings }\end{array}$ \\
\hline Disturbed soil & 11 & 0 & 0 & 0 \\
\hline Roadside & 142 & 0 & 0 & 0 \\
\hline Agricultural & 67 & 0 & 0 & 0 \\
\hline Citrus orchard & 394 & 0 & 0 & 0 \\
\hline Bamboo & 9 & 0 & 0 & 0 \\
\hline Lawn/mown & 198 & 0 & 0 & 0 \\
\hline Field/pasture & 379 & 4 & 3 & 0.0079 \\
\hline Eucalyptus plantation, managed ${ }^{\dagger}$ & 631 & 58 & 38 & 0.0602 \\
\hline "Failed" Eucalyptus plantation ${ }^{\ddagger}$ & 35 & 7 & 5 & 0.1429 \\
\hline Young pine plantation & 13 & 0 & 0 & 0 \\
\hline Pine plantation & 374 & 2 & 1 & 0.0027 \\
\hline Suburban wooded & 13 & 0 & 0 & 0 \\
\hline Partially wooded & 38 & 1 & 1 & 0.0263 \\
\hline Forest, unmanaged & 175 & 0 & 0 & 0 \\
\hline Wetland & 360 & 13 & 9 & 0.0250 \\
\hline
\end{tabular}

${ }^{\dagger}$ Not all plots in this land cover type fell within the plantation of interest, as some plantations neighbored other Eucalyptus plantations. Plots in this land cover type were both inside and outside the plantation of interest. ${ }^{*}$ This land cover type represents areas where Eucalyptus was originally planted, but where the survival was low enough that the sites were not managed with the rest of the plantation. Plots in this land cover type were outside of the plantation of interest.

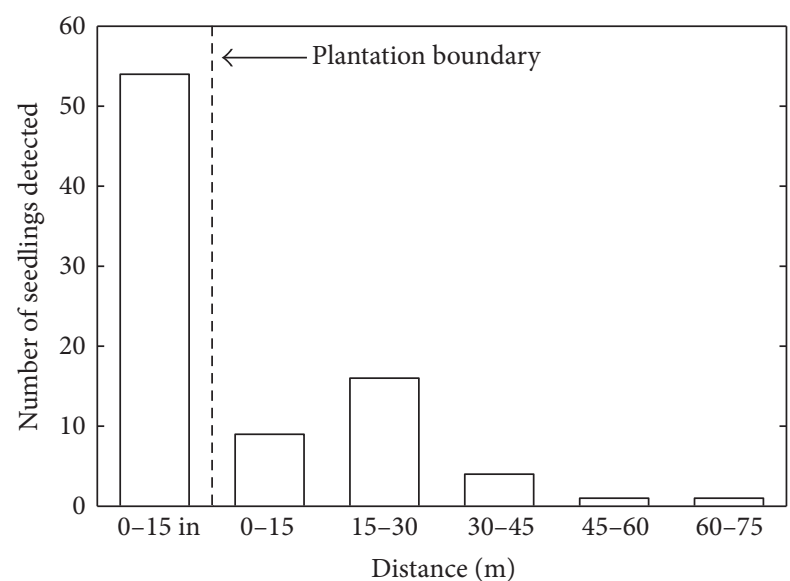

FIGURE 2: Eucalyptus seedling detections from all sites surveyed in this study.

Other factors we considered as potentially being influential to the establishment of seedlings were the age and size of the plantations (and thus maturity and number of potential trees producing seed, and increasing propagule pressure). Correlation analysis examining the relationship between plantation age showed that there was a positive relationship between stand age and seedling establishment $\left(R^{2}=0.379\right.$, Figure $\left.4(a)\right)$. Correlation analysis examining the relationship between plantation size and number of seedlings detected also showed a positive relationship $\left(R^{2}=0.429\right.$, Figure 4(b)).

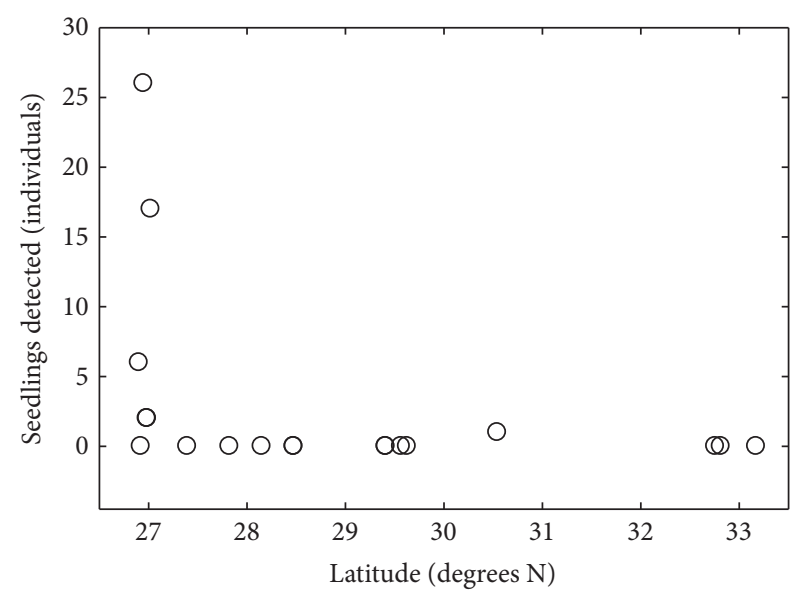

FIGURE 3: Relationship between latitude and Eucalyptus seedling establishment. Points represent each of the 19 sites surveyed. Because some sites were very close to one another (i.e., similar latitude coordinates) some of the points on the graph will overlap with some being obscured.

When we examined the potential influence of surrounding land-uses on the establishment of seedlings inside or outside the plantation boundaries, we found that all of the seedlings were found in 6 of the 15 predominant land-cover categories that we identified. These six land-uses included (1) managed Eucalyptus plantation, (2) wetland, (3) failed Eucalyptus plantation, (4) hayfield/pasture, (5) pine plantation, and (6) partially wooded. The land cover type that had the highest frequency of plots containing Eucalyptus 


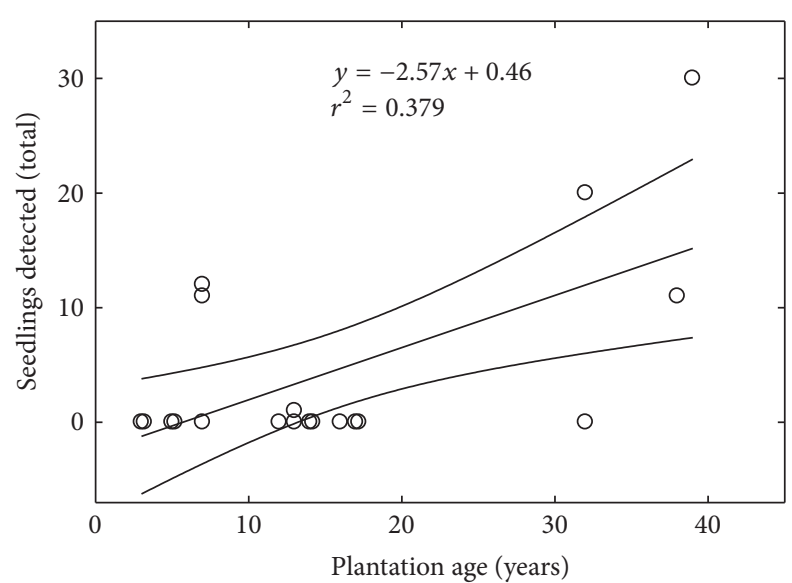

(a)

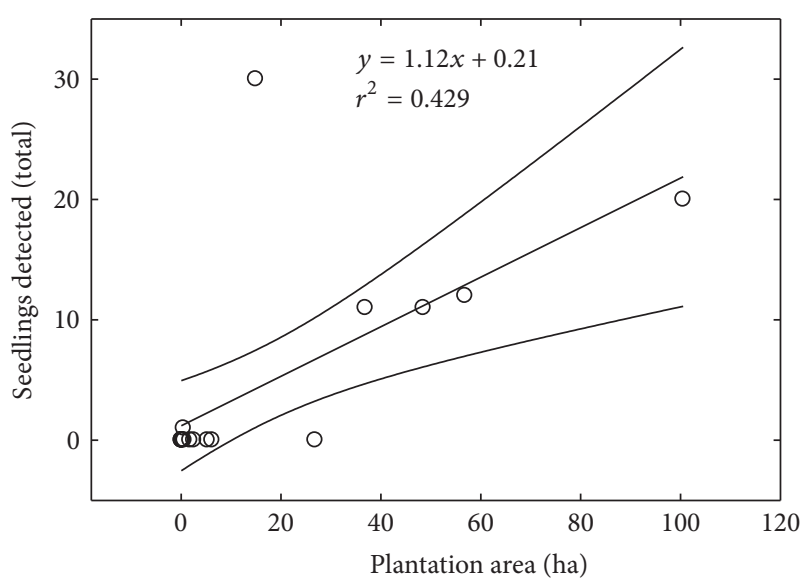

(b)

FIGURE 4: Relationship between (a) the age of the oldest trees planted at each plantation, and Eucalyptus seedling establishment; and (b) size of the plantation and Eucalyptus seedling establishment. Because some plantations were very similar in size and also had few or no seedlings established, some points on the graph will overlap with some being obscured. Confidence intervals are $95 \%$ confidence.

seedlings was the "failed Eucalyptus plantation" category with $14 \%$ of transects in this category containing seedlings (Table 2). The next most frequently sampled habitat type with plots containing seedlings was the managed Eucalyptus plantations with $\sim 6 \%$ of plots containing seedlings. All the other land-use types with seedlings had frequencies of less than $3 \%$, including wetlands, in spite of the fact that wetlands represented the only habitat type that had not been previously planted to Eucalyptus with a relatively high number of seedlings.

Results of the logistic regression analysis showed that the only variables that were significantly related to seedling establishment were latitude $(P=0.0011)$, canopy cover $(P<0.0001)$, and the previous or current presence of planted Eucalyptus $(P=0.0002$; Table 3$)$. Other tested variables (wetland habitat type and percent bare ground) were not significantly related to Eucalyptus seedling establishment.

\section{Discussion}

The dataset produced by our survey is from a relatively small number of plantations, and with fairly intensive landuse and management in the surroundings. We recommend much more sampling before any regulatory decisions can be made regarding the wide-scale planting of Eucalyptus species. Nevertheless, this survey represents the first to our knowledge to attempt a field-based assessment of the potential for Eucalyptus to spread from plantation settings in the southeastern USA. Overall, the results of our survey suggest, that under current conditions, the establishment of seedlings near Eucalyptus plantations is a rare event, particularly north of latitude $27^{\circ} \mathrm{N}$. However, south of $27^{\circ} \mathrm{N}$, we did detect seedlings more frequently in particular landuse types, and this inspires caution with regard to monitoring plantations for potential escape of seedlings into habitats where Eucalyptus is not desirable.

The fact that we found a positive relationship between plantation age and the establishment of seedlings in our survey is deserving of special attention. Two of the oldest plantations were established and managed as seed orchards (Table 1), and thus is should not be surprising, perhaps that these sites yielded the highest rates of seedling detections. Trees in these plantations would have been open grown and widely spaced for the purpose of maximizing seed production. In actual practice, the management of large Eucalyptus plantations in the bioenergy context would tend to prevent plantations from ever reaching the ages that were most strongly related to seedling establishment, as most bioenergy plantations would be likely to be harvested between age 5 and 7. From the perspective of monitoring to avoid the unintentional spread of planted eucalypts into surrounding landuses, this finding suggests that seed orchards or advanced regeneration seedling orchards should have higher priority than operational bioenergy plantations for monitoring.

The results of the logistic regression provide further strong evidence that certain areas are more likely to exhibit seedling establishment and may aid in setting priorities for future monitoring of potential invasions. The parameters produced in logistic regression are often interpreted in terms of odds ratios, which are calculated by taking the exponential of the parameter, and which describe the strength of association between predictor and response variable. The odds ratio represents the change in odds of the outcome of a binary response variable for a one-unit change in the predictor variable. We found that for every one degree decrease in latitude, the odds of finding a seedling in a plot (versus not finding a seedling in a plot) increase by 3.7. The odds of finding a seedling in a plot that had previously been planted to Eucalyptus were 6.3 times greater than that of finding a seedling in a plot that had not been previously planted to Eucalyptus. These results suggest a significant difference in the probability of naturalization versus invasion of Eucalyptus, with a greater chance of naturalization, and an increased likelihood of Eucalyptus establishment in the more southern areas that we sampled.

Our findings are quite similar to an effort in South Africa to rapidly develop a baseline dataset and management 
TABLE 3: Results of logistic regression analysis of continuous (latitude, canopy cover, and percent bare ground), and binary (wetland, Eucalyptus planted previous or present) variables from the sampling survey. Canopy cover and percent bare ground data for one South Carolina site were not collected and so this site was excluded from the analysis.

\begin{tabular}{|c|c|c|c|c|c|}
\hline \multicolumn{6}{|c|}{ Analysis of maximum likelihood estimates. } \\
\hline Parameter & d.f. & Estimate & Standard error & Wald chi-square & $\operatorname{Pr}>$ ChiSq \\
\hline Intercept & 1 & 32.2962 & 10.8439 & 8.8701 & 0.0029 \\
\hline Latitude & 1 & -1.3125 & 0.4021 & 10.6516 & 0.0011 \\
\hline Canopy cover & 1 & 0.0244 & 0.00514 & 22.5468 & $<0.0001$ \\
\hline Bare ground & 1 & -0.1080 & 0.0904 & 1.4301 & 0.2317 \\
\hline Eucalyptus planted & 1 & 0.9204 & 0.2492 & 13.6381 & 0.0002 \\
\hline Wetland & 1 & 0.4417 & 0.2846 & 2.4086 & 0.1207 \\
\hline
\end{tabular}

guideline for species of Eucalyptus that have been planted in South Africa for decades [11]. These authors utilized similar definitions of "invasive" and "naturalized" as we have used, and although their data collection methodology (rapid visual determinations of spread) was quite different from that employed in our study (spatially explicit, plot-based, and with other environmental data collected), their results were essentially similar. Indeed, these authors point out that Eucalyptus in general are "mediocre invaders" and count this observation as "puzzling." The South African survey did find that two species (E. camaldulensis and E. grandis) were of special concern in South Africa [11], and this is notable because both of these species are also represented in the plantations examined in our study, although only E. grandis was observed to produce offspring in our plots.

There are several potential explanations for why we observed a somewhat limited spread and invasive behavior in the plantations where we did our sampling. One factor influencing the relative "invasiveness" of plants is the propagule pressure (i.e., the density or total number of reproductive plants in an area) required for establishment and spread of populations. There are different patterns for propagule pressure dose-response curves among invasive species [24], including linear, exponential, and sigmoidal, but the pattern that applies to Eucalyptus in the southeastern USA is not known. It is possible that a density of propagules that would promote widespread establishment of seedlings outside of plantations has not been achieved in the plantings evaluated in this study.

Another factor related to propagule pressure, and involved in the establishment and spread of invasive plants, is the presence of suitable means of pollination and thus production of enough viable seed to enhance the spread of the plant. Although there are more than 700 species in the genus, and pollinator relationships are diverse, most Eucalyptus spp. are pollinated by bees and wasps. Vieira et al. [25] showed that the diversity of bees and wasps was reduced in Eucalyptus plantations in Portugal. It is possible that the optimal or preferred pollinators for the Eucalyptus species examined in this study do not exist in the native pollinator fauna in Florida or South Carolina. However, our observations of seedling establishment within several Eucalyptus stands from our survey suggest that viable seed is being produced, and that pollination therefore should not be a limiting factor in the reproduction of the plants. This observation may be related to the fact that some of the species examined in our study are self-pollinators and do not require pollination by other organisms.

Another factor that influences the successful spread of invasive plant and animal species is the fact that new habitats where species are introduced often lack the suite of natural enemies which would keep that species in check in its native range. This certainly seems to be the case for Eucalyptus in California where several species have been planted for $\sim 150$ years. For most of that time, Eucalyptus has grown in conditions where its native herbivores have been absent. However, the recent introduction of insect herbivores from Australia that are specialists on Eucalyptus is a concern for the long-term productivity of planted trees in California [26] and may limit the rate of spread of trees that have escaped cultivation. In Chile, there is evidence that herbivory by introduced vertebrates may limit the invasion success of Eucalyptus [12], and in Brazil, da Silva et al. [13] noted that native leaf-cutter ants (Atta spp.) seemed to prefer the leaves of Eucalyptus over the native species, and they proposed that this may account for the poor seedling establishment they observed in their study. There are high densities of large herbivores native to the southeastern USA (white-tailed deer, Odocoileus virginianus), but the extent to which these animals may be feeding on Eucalyptus is unknown and should be explored further.

Another consideration that may have some bearing on why we saw a limited spread of Eucalyptus seedlings in our study is the observation that many locations across the globe where Eucalyptus is known to become invasive and pose significant ecological risks have Mediterranean climate conditions. Although several eucalypt species are known to naturalize readily in subtropical and temperate climates, there is limited evidence of many species becoming invasive. Indeed, in our study and another study conducted in subtropical climates [13], the spread of Eucalyptus seems to be limited by at least one of a number of factors. One such limiting factor may be that the fungal symbionts of the eucalypt species in question are not able to fruit and disperse propagules into the surrounding soils. Díez hypothesized [27] that the native ectomycorrhizas of eucalypts may require a drying down of the soil (as would be typical of a Mediterranean climatic region) in order for the fungi to fruit, and that this may partially explain why these fungi do not seem to disperse very well in regions where such regular dry periods do not 
occur (such as at our study sites). This may be suggestive at present of decreased risk of Eucalyptus invasion in the southeastern USA, but continued vigilance over coming decades will be required as climate changes occur in the region, particularly if these tend as predicted (US Global Climate Change Research Program, 2009) toward greater seasonality in rainfall and higher temperatures (conditions more comparable to Mediterranean climates). One final consideration which argues for caution with regard to the potential for any exotic plant species to spread is found in the case of Eucalyptus conferruminata. This species has been extant in California for at least 50 years, but only recently has been observed to produce seedlings [14], suggesting that there can be significant lag times associated with the naturalization/invasion process, and underpinning concerns over the role of short-term evolution and hybridization as a mechanism of the development of invasive attributes among exotic plants [28].

In conclusion, results from our survey indicate that Eucalyptus seedlings can establish with some regularity within planted stands, and this shows a strong likelihood that the species used in plantation forestry will become naturalized in the southeastern USA. However, like other workers in subtropical climates, we did not find strong evidence that Eucalyptus is spreading rapidly, or in great numbers, away from the boundaries of plantations. This was particularly true when the land surrounding the sampled Eucalyptus plantings was intensively managed. For example, we did not detect a single seedling in agricultural, suburban, or citrus orchard land-uses, and this is probably related to the intensity of management common in these areas. On the other hand, our sampling did detect Eucalyptus seedlings in land cover types that were less intensively managed (e.g., partially wooded sites), and this inspires caution with regard to the potential for the plant to spread into unmanaged areas. The sampling protocol used in our study was robust and efficient, and we suggest that sampling of this kind may serve as an effective monitoring tool for future plantings of Eucalyptus in the southeastern USA. Such monitoring will be imperative if questions involving plantation area, propagule pressure, and movement into unmanaged areas are to be resolved. Furthermore, such monitoring will be critical if the potential risks of Eucalyptus becoming problematic invasive species are to be responsibly mitigated.

\section{References}

[1] R. S. Zalesny Jr., M. W. Cunningham, R. B. Hall et al., "Woody biomass from short rotation energy crops," in Sustainable Production of Fuels, Chemicals, and Fibers from Forest Biomass, J. Y. Zhu, X. Zhang, and J. Pan, Eds., vol. 1067 of ACS Symposium Series, pp. 27-63, American Chemical Society, Washington, DC, USA, 2011.

[2] J. Gan and C. T. Smith, "Availability of logging residues and potential for electricity production and carbon displacement in the USA," Biomass and Bioenergy, vol. 30, no. 12, pp. 1011-1020, 2006.

[3] R. Gonzalez, T. Treasure, J. Wright et al., "Exploring the potential of Eucalyptus for energy production in the Southern
United States: financial analysis of delivered biomass. Part I," Biomass and Bioenergy, vol. 35, no. 2, pp. 755-766, 2011.

[4] M. H. Langholtz, D. R. Carter, and D. L. Rockwood, Assessing the Economic Feasibility of Short-Rotation Woody Crops in Florida, Circular 1516, IFAS Extension, University of Florida, Gainesville, Fla, USA, 2010.

[5] R. Rousseau, Short Rotation Woody Crops, vol. 2611, Extension Service of Mississippi State University, Starkville, Miss, USA, 2010.

[6] D. L. Rockwood, D. R. Carter, M. H. Langholtz, and J. A. Stricker, "Eucalyptus and Populus short rotation woody crops for phosphate mined lands in Florida USA," Biomass and Bioenergy, vol. 30, no. 8-9, pp. 728-734, 2006.

[7] M. D. Coleman and J. A. Stanturf, "Biomass feedstock production systems: economic and environmental benefits," Biomass and Bioenergy, vol. 30, no. 8-9, pp. 693-695, 2006.

[8] J. N. Barney and J. M. DiTomaso, "Nonnative species and bioenergy: are we cultivating the next invader?" BioScience, vol. 58, no. 1, pp. 64-70, 2008.

[9] K. Ferdinands, J. Virtue, S. B. Johnson, and S. A. Setterfield, “'Bio-insecurities': managing demand for potentially invasive species in the bioeconomy," Current Opinion in Environmental Sustainability, vol. 3, no. 1-2, pp. 43-49, 2011.

[10] B. W. van Wilgen, G. G. Forsyth, D. C. Le Maitre et al., "An assessment of the effectiveness of a large, national-scale invasive alien plant control strategy in South Africa," Biological Conservation, vol. 148, pp. 28-38, 2012.

[11] G. G. Forsyth, D. M. Richardson, P. J. Brown, and B. W. Van Wilgen, "A rapid assessment of the invasive status of Eucalyptus species in two South African provinces," South African Journal of Science, vol. 100, no. 1-2, pp. 75-77, 2004.

[12] P. I. Becerra and R. O. Bustamante, "The effect of herbivory on seedling survival of the invasive exotic species Pinus radiata and Eucalyptus globulus in a Mediterranean ecosystem of Central Chile," Forest Ecology and Management, vol. 256, no. 9, pp. 1573-1578, 2008.

[13] P. H. M. da Silva, F. Poggiani, A. M. Sebbenn, and E. S. Mori, "Can Eucalyptus invade native forest fragments close to commercial stands?" Forest Ecology and Management, vol. 261, no. 11, pp. 2075-2080, 2011.

[14] M. Ritter and J. Yost, "Diversity, reproduction, and potential for invasiveness of Eucalyptus in California," Madroño, vol. 56, pp. 155-167, 2009.

[15] D. L. Rockwood, "History and status of Eucalyptus improvement in Florida," International Journal of Forestry Research, vol. 2012, Article ID 607879, 10 pages, 2012.

[16] M. Rejmánek and D. M. Richardson, "Eucalypts," in Encyclopedia of Biological Invasions, D. Simberloff and M. Rejmánek, Eds., pp. 203-209, University of California Press, Berkeley, Calif, USA, 2011.

[17] D. Boyd, "Eucalyptus globulus," in Invasive Plants of California's Wildlands, C. C. Bossard, J. M. Randall, and M. C. Hoshovsky, Eds., pp. 183-187, 2000.

[18] P. C. Pheloung, P. A. Williams, and S. R. Halloy, "A weed risk assessment model for use as a biosecurity tool evaluating plant introductions," Journal of Environmental Management, vol. 57, no. 4, pp. 239-251, 1999.

[19] D. R. Gordon, D. A. Onderdonk, A. M. Fox, and R. K. Stocker, "Consistent accuracy of the Australian weed risk assessment system across varied geographies," Diversity and Distributions, vol. 14, no. 2, pp. 234-242, 2008.

[20] D. R. Gordon, K. J. Tancig, D. A. Onderdonk, and C. A. Gantz, "Assessing the invasive potential of biofuel species proposed for 
Florida and the United States using the Australian Weed Risk Assessment," Biomass and Bioenergy, vol. 35, no. 1, pp. 74-79, 2011.

[21] D. M. Richardson, P. Pyšek, M. Rejmánek, M. G. Barbour, F. D. Panetta, and C. J. West, "Naturalization and invasion of alien plants: concepts and definitions," Diversity and Distributions, vol. 6, no. 2, pp. 93-107, 2000.

[22] T. M. Blackburn, P. Pyšek, S. Bacher et al., "A proposed unified framework for biological invasions," Trends in Ecology and Evolution, vol. 26, pp. 333-339, 2011.

[23] R. H. Green and R. C. Young, "Sampling to detect rare species," Ecological Applications, vol. 3, no. 2, pp. 351-356, 1993.

[24] J. L. Lockwood, P. Cassey, and T. Blackburn, "The role of propagule pressure in explaining species invasions," Trends in Ecology and Evolution, vol. 20, no. 5, pp. 223-228, 2005.

[25] L. C. Vieira, N. G. Oliveira, and S. F. Gayubo, "On the use of Apiformes and Spheciformes (Insecta: Hymenoptera) populations as a management tool," Biodiversity and Conservation, vol. 20, no. 3, pp. 519-530, 2011.

[26] T. D. Paine, J. G. Millar, and K. M. Daane, "Accumulation of pest insects on eucalyptus in California: random process or smoking gun," Journal of Economic Entomology, vol. 103, no. 6, pp. 1943-1949, 2010.

[27] J. Díez, "Invasion biology of Australian ectomycorrhizal fungi introduced with eucalypt plantations into the Iberian Peninsula," Biological Invasions, vol. 7, no. 1, pp. 3-15, 2005.

[28] N. C. Ellstrand and K. A. Schierenbeck, "Hybridization as a stimulus for the evolution of invasiveness in plants?" Proceedings of the National Academy of Sciences of the United States of America, vol. 97, no. 13, pp. 7043-7050, 2000. 

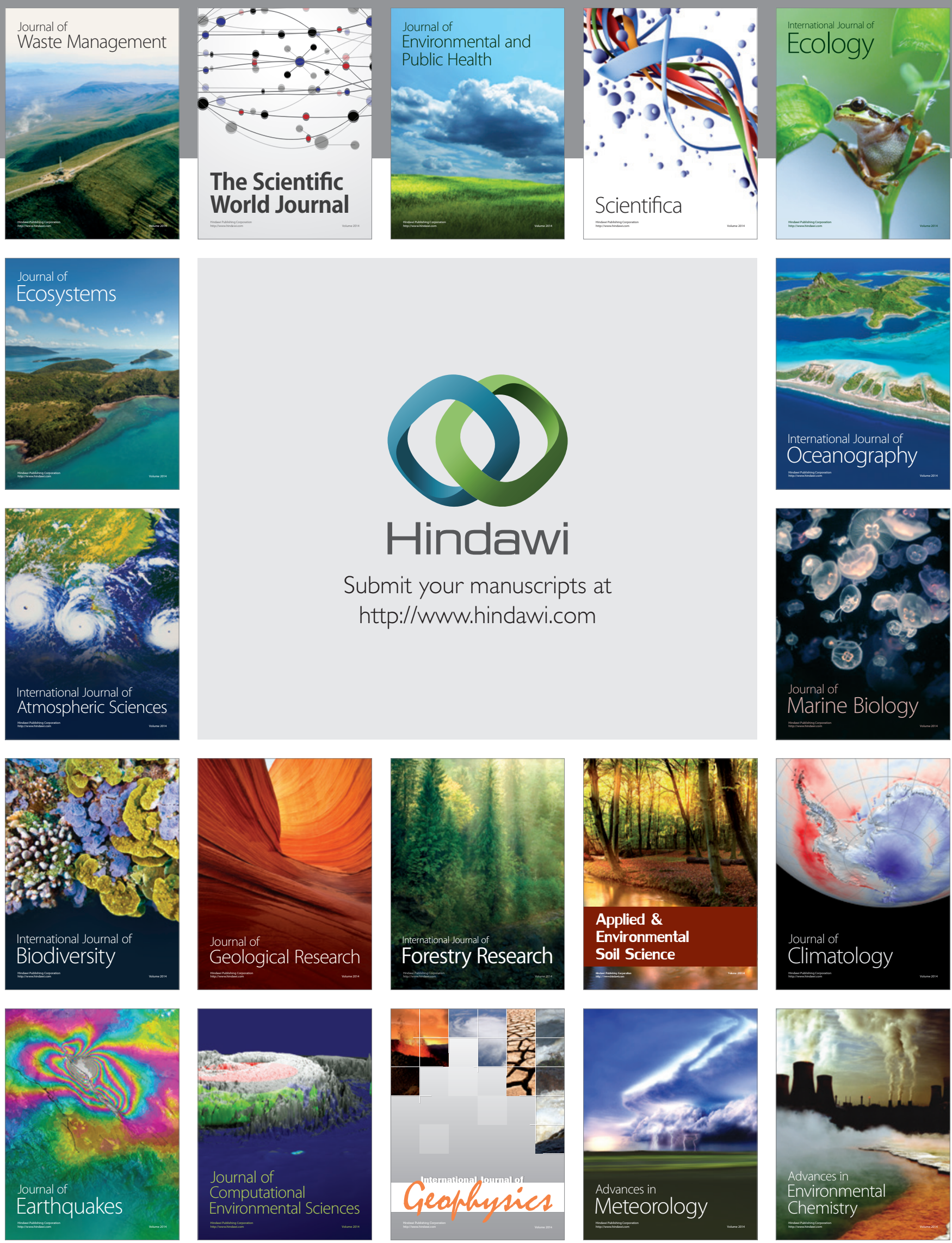